DOI: http://dx.doi.org/10.33846/ghs6107

\title{
Pengaruh Edukasi terhadap Pengetahuan dan Sikap Petani Rumput Laut dalam Penggunaan APD untuk Pencegahan Dermatitis Kontak di Ohoi Nngilngof Kecamatan Manyeu Kabupaten Maluku Tenggara
}

\author{
Rahel Metanfanuan (koresponden) \\ Program Studi Keperawatan Tual Poltekkes Kemenkes Maluku; akemetanfanuan@gmail.com \\ Jonathan Kelabora \\ Program Studi Keperawatan Tual Poltekkes Kemenkes Maluku; thankelab@gmail.com
}

\begin{abstract}
ABSTRAK
Penyakit akibat kerja merupakan beban kesehatan dan ekonomi karena tidak hanya membutuhkan layanan dan biaya kesehatan, tetapi juga mengurangi produktivitas pekerja. Salah satu penyakit akibat kerja yang paling banyak dijumpai yaitu dermatitis kontak yang terkena pada petani rumput laut. Penelitian ini menganalisis pengaruh pendidikan terhadap pengetahuan dan sikap petani rumput laut dalam penggunaan APD untuk pencegahan dermatitis kontak. Desain penelitian dengan pendekatan kuantitatif, menggunakan metode eksperimen semu atau Eksperimen Kuasi dengan Pre-test dan postuji satu desain kelompok. dengan populasi petani rumput laut yang berlokasi di Ohoi Ngilngoff, Kecamatan Manyeu, Kabupaten Maluku Tenggara. Teknik pengambilan sampel adalah total sampel dengan jumlah responden 62 orang. Analisis penelitian menggunakan paired sample T-test. Hasil penelitian menunjukkan ada pengaruh pendidikan terhadap pengetahuan $(p=0,0000$ dan sikap $(p=$ $0,0000)$ petani rumput laut. Hasil analisis pengetahuan dan sikap, rerata nilai pengetahuan adalah 3,6613 > 2,9032 dan Sikap 2,0000 > 1,6290. Kesimpulan: Edukasi dapat memiliki pengaruh terhadap peningkatan pengetahuan dan sikap dengan nilai p $0,000<0,005$. Berdasarkan nilai rata-rata untuk pengetahuan 3,6613 > 2,9032 dan sikap 2,0000 > 1,6290. Ini berarti bahwa ada pengaruh edukasi terhadap pengetahuan dan sikap petani rumput laut dalam penggunaan APD untuk pencegahan dermatitis kontak.
\end{abstract}

Kata kunci: dermatitis kontak; APD; pengetahuan; sikap

\section{PENDAHULUAN}

\section{Latar Belakang}

Penyakit akibat kerja (PAK) merupakan masalah penting di dunia, termasuk di Indonesia. International Labour Organization (ILO) pada tahun 2013 menyatakan bahwa 1 pekerja di dunia meninggal setiap 15 detik karena kecelakaan kerja dan 160 pekerja mengalami sakit akibat kerja.(1) Di Indonesia kecelakaan kerja dan Penyakit akibat kerja menjadi beban kesehatan dan ekonomi karena bukan hanya membutuhkan pelayanan dan biaya kesehatan, namun juga menurunkan produktifitas para pekerja. ${ }^{(2)}$ Penyakit Akibat Kerja (PAK) merupakan penyakit yang berhubungan dengan pekerjaan dan kecelakaan kerja yang dapat menyebabkan kecacatan bahkan kematian. Salah satu penyakit akibat kerja yang paling banyak dijumpai yaitu dermatitis kontak yang terkena pada petani rumput laut. Dermatitis kontak merupakan penyakit kulit yang umumnya dapat terjadi secara berulang terhadap seseorang dalam bentuk peradangan kulit (epidermis dan dermis) sebagai respon terhadap pengaruh faktor eksogen dan atau faktor endogen, yang menimbulkan kelainan klinis berupa lisensi polimorfik (eritema, edema, papul, vesikel, skuama, likenifikasi) dan keluhan gatal. ${ }^{(3)}$ Faktor- faktor yang mempengaruhi terjadinya dermatitis kontak yaitu faktor eksogen dan faktor endogen. Faktor eksogen meliputi tipe, karakteristik agen, karakteristik paparan serta lingkungan. Sedangkan faktor endogen meliputi faktor genetik, jenis kelamin, usia, ras, lokasi kulit, dan riwayat atopic. ${ }^{(4)}$

Gangguan kesehatan kulit (Dermatitis kontak) pada petani rumput laut merupakan salah satu penyakit berbasis lingkungan. Penyakit ini timbul akibat dari beberapa faktor lingkungan, karakteristik paparan, karakteristik agen, dan faktor individu. Higiene perorangan yang tidak memadai dapat mengakibatkan infeksi jamur, bakteri, virus, parasit, gangguan kulit dan keluhan lainnya. Untuk dapat menciptakan kondisi yang aman dan sehat dalam bekerja diperlukan adanya unsur - unsur dan prinsip - prinsip keselamatan dan kesehatan kerja. Menurut Sutrisno dan Kusmawan Ruswandi (2007) prinsip dan unsur keslamatan dalam bekerja antara lain adalah adanya APD (Alat Pelindung Diri) di tempat kerja. Alat pelindung perlu digunakan petani rumput laut saat bekerja untuk melindungi seluruh tubuh atau sebagian tubuh terhadap kemungkinan adanya potensi bahaya atau virus, bakteri, maupun parasit. ${ }^{(5)}$ Kondisi ini sangat bergantung kepada konsep pengetahuan dan sikap seseorang. 
Pengetahuan adalah merupakan hasil "Tahu" dan ini terjadi setelah orang mengadakan penginderaan terhadap satu objek tertentu. Penginderaan terhadap objek terjadi melalui panca indra manusia yakni penglihatan, pendengaran, penciuman, rasa dan raba dengan sendiri. Pada waktu pengindraan sampai menghasilkan pengetahuan tersebut sangat dipengaruhi oleh intensitas perhatian persepsi terhadap obyek. ${ }^{(6)}$ Sikap adalah respon tertutup seseorang terhadap suatu stimulus/objek sehingga manifestasinya tidak langsung dapat dilihat tetapi hanya bisa dapat ditafsirkan terlebih dahulu dari perilaku. Sikap secara realita menunjukkan adanya kesesuaian respon terhadap stimulus tertentu (Sunaryo, 2004). Azwar (2013) menjelaskan bahwa faktor-faktor yang mempengaruhi pembentukkan sikap adalah pengalaman pribadi, pengaruh orang lain yang dianggap penting, pengaruh kebudayaan, media masa, lembaga pendidikan dan lembaga agama, pengaruh faktor emosional."Sikap adalah kecenderungan untuk merespon (secara positif atau negatif) terhadap orang, obyek atau situasi tertentu. ${ }^{(7)}$ misalnya pekerja petani rumput laut mau menggunakan APD saat bekerja untuk menghindari terjadinya dermatitis kontak .

Data dari Puskesmas Debut masyarakat Ohoi Ngilngof yang mengalami dermatitis kontak pada 3 tahun terakhir sebanyak 66 orang dengan rincian sebagai berikut, tahun 2017 bejumlah 16 orang, tahun 2018 berjumlah 29 orang, tahun 2019 berjumlah 21 orang. Data Ohoi Ngilngof Total jumlah penduduk Ohoi Ngilngof 1.334 jiwa yang terdiri dari laki-laki 619 jiwa dan perempuan 715 jiwa. Dari jumlah penduduk Ohoi yang mata pencaharian sebagai petani rumput laut sebanyak 62 Orang, petani 22 orang, PNS 32 orang, wiraswasta 19 orang, tidak bekerja 948 orang, belum bekerja 251 orang (Data kependudukan Ohoi tahun 2019)

\section{METODE}

Jenis Penelitian yang digunakan adalah penelitian kuantitatif dengan menggunakan metode eksperimen semu atau Quasi Experimen dengan rancangan Pre test Post test one group design. ${ }^{(8)}$ Rancangan ini digunakan untuk mengetahui apakah ada pengaruh dilakukan Pre test (01) pada responden, dan diikuti intervensi $(X)$ pada reponden, setelah beberapa waktu dilakukan post test (02) pada responden. Populasi dalam penelitian ini adalah petani rumput laut dengan teknik total sampling dengan jumlah responden 62 orang. Penelitian ini diawali dengan survei pendahuluan dan selanjutnya pengurusan ijin penelitian. Penelitian dilaksanakan pada bulan Oktober sampai dengan bulan November 2019. Pengumpulan data dilakukan dengan cara kuisioner dibagikan kepada 62 responden. Enumerataor membagikan kuisioner kepada responden untuk diisi, hasilnya disebut pre test (01). Setelah hasil pretes dikumpulkan. Sesi berikut peneliti memberikan intervensi berupa Edukasi/penyuluhan kesehatan kepada responden. Setelah selesai diberikan penyuluhan, enumerator membagikan kuisioner yang sama kepada responden untuk diisi yang hasilnya disebut post test (02).

Pengolahan data dilakukan dengan tahap: Editing, coding, tabulation, entry data dan cleaning. Kuisioner dilakukan dengan uji validitas dan reliabilitas dan hasilnya menunjukkan valid dan reliebel.

\section{HASIL}

Tabel 1. Pengetahuan responden pre edukasi

\begin{tabular}{|c|c|c|}
\hline Pengetahuan & Frekuensi & Persentase \\
\hline Kurang & 2 & 3.2 \\
\hline Cukup & 11 & 17.7 \\
\hline Baik & 40 & 64.5 \\
\hline Sangat Baik & 9 & 14.5 \\
\hline Total & 62 & 100 \\
\hline
\end{tabular}

Tabel 1 menunjukkan bahwa pengetahuan responden pre edukasi hasilnya pengetahuan baik lebih banyak kemudian diikuti pengetahuan cukup baik, sangat baik, dan kurang baik

Tabel 2. Pengetahuan responden post edukasi

\begin{tabular}{|c|c|c|}
\hline Pengetahuan & Frekuensi & Persentase \\
\hline Cukup & 1 & 1.6 \\
\hline Baik & 19 & 30.6 \\
\hline Sangat Baik & 42 & 76.7 \\
\hline Total & 62 & 100 \\
\hline
\end{tabular}


Table 2 menunjukkan bahwa pengetahuan responden post edukasi hasilnya pengetahuan sangat baik lebih banyak kemudian diikuti pengetahuan baik dan cukup baik

Tabel 3. Hasil analisis uji paired sampel T-test pengetahuan responden

\begin{tabular}{|l|c|c|c|c|}
\hline Dermatitis kontak & Mean & t-hitung & Df & $p$ value \\
\hline Pengetahuan Pre test & 2.9032 & -7.626 & 61 & 0,000 \\
\hline Pengetahuan Post test & 3.6613 & & & \\
\hline
\end{tabular}

Table 3 menunjukkan bahwa hasil analisis dengan menggunakan uji sampel berpasangan diperoleh nilai $t$ hitung pengetahuan sebelum dan sesudah edukasi yaitu -7.626 dengan nilai $p$ value $0,000<0,005$ maka Ho ditolak, dan Ha diterima berarti pengetahuan sebelum dan sesudah edukasi tidak sama. Hasil penelitian juga menunjukkan rerata nilai mean pengetahuan pre edukasi 2.9032 dan pengetahuan post edukasi 3,6613 . Artinya secara statistik terdapat perbedaan yang signifikan nilai mean pengetahuan post edukasi 3,6613 > 2.9032 pengetahuan pre edukasi

Tabel 4. Hasil analisis uji paired sampel T-test Sikap responden

\begin{tabular}{|c|c|c|c|c|}
\hline Dermatitis kontak & Mean & t-hitung & Df & $p$ value \\
\hline Sikap Pre test & 1.6290 & -5.998 & 61 & 0,000 \\
\hline Sikap post test & 2.0000 & & & \\
\hline
\end{tabular}

Table 4 menunjukkan bahwa hasil analisis dengan menggunakan uji $t$ sampel berpasangan diperoleh nilai $t$ hitung sikap sebelum edulasi dan sesudah edukasi yaitu -5.998 dengan nilai $p$ value $0,000<0,005$ maka Ho ditolak, menerima Ha berarti sikap sebelum edukasi dan sesudah edukasi terdapat perbedaan. Hasil pada table 4 juga menunjukkan bahwa nilai mean sikap pra edukasi 1.6290 dan sikap post edukasi nilai 2.0000 Artinya secara statistik terdapat perbedaan yang signifikan nilai mean sikap post edukasi $2.0000>1.6290$ nilai sikap pre edukasi

\section{PEMBAHASAN}

Dari hasil penelitian diketahui bahwa pengetahuan responden tentang dermatitis kontak sebelum diberikan edukasi rata-rata berpengetahuan cukup dan baik (17.7\%-64.5\%), sementara pengetahuan responden setelah diberikan edukasi meningkat menjadi sangat baik $(71,43 \%)$. Hasil penelitian juga menunjukkan rerata nilai mean pengetahuan sebelum edukasi 2.9032 dan pengetahuan sesudah edukasi 3,6613. Artinya secara statistik terdapat perbedaan yang signifikan nilai mean pengetahuan setelah edukasi 3,6613 > 2.9032 pengetahuan sebelum edukasi.

Hasil penelitian juga menunjukkan sikap responden sebelum dilakukan edukasi nilai mean 1.6290, dan sikap responden setelah edukasi nilai mean menjadi 2.0000. Artinya nilai mean setelah edukasi $2.0000>1.6290$. Hasil penelitian ini menunjukkan bahwa ada pengaruh edukasi terhadap pengetahuan dan sikap petani rumput laut dalam penggunaan APD untuk pencegahan dermatitis kontak.

Bila dilihat dari perbandingan rerata nilai pengetahuan dan sikap responden sebelum dan sesudah dilakukan edukasi/penyuluhan, maka didapati bahwa ada perbedaan rerata nilai pengetahuan dan sikap responden sebelum dan sesudah dilakukan edukasi tentang dermatitis kontak maka peningkatan rerata nilai pengetahuan dan sikap responden signifikan $(p<0,05)$. Hasil penelitian ini sejalan dengan penelitian yang dilakukan Gemim Sahputra dan Halono Siregar (2013) Di Kecamatan Percut Sei Tuan dikemukakan bahwa, ada pengaruh penyuluhan metode ceramah $(p=0,0001)$ dan diskusi kelompok $(p=0,0001)$ terhadap peningkatan pengetahuan dan sikap pekerja las tentang APD. ${ }^{(9)}$ Hasil penelitian ini didukung oleh penelitian Murtiyani di Kabupaten Mojokerto dikemukakan bahwa terdapat pengaruh metode penyuluhan dengan leaflet terhadap pengetahuan, sikap dan perilaku keluarga dalam pemberantasan DBD. ${ }^{(10)}$

Hasil penelitian ini dikuatkan juga oleh penelitian yang mengemukakan bahwa diskusi kelompok efektif dalam meningkatkan pengetahuan dan sikap tentang kesehatan reproduksi pada remaja di Yayasan Pendidikan Harapan Mekar Medan.(Permatasari, 2010).(11) Hal ini juga sejalan dengan penelitian yang dilakukan oleh Arifah yang mengemukakan bahwa terdapat pengaruh secara statistik terdapat peningkatan pengetahuan dan sikap wanita tentang menopause pada pedidikan kesehatan dengan modul. ${ }^{(12)}$

Menurut WHO dalam Notoatmodjo menyatakan salah satu strategi untuk memperoleh perubahan pengetahuan adalah pendidikan dimana cara ini diawali dengan cara pemberian informasi 
kesehatan. Dengan memberikan informasi lewat edukasi/penyuluhan tentang cara-cara hidup sehat, cara pemeliharaan kesehatan dan sebagainya akan meningkatkan pengetahuan masyarakat tentang hal tersebut. ${ }^{(13)}$ Pengetahuan merupakan hasil dari tahu dan terjadi setelah melakukan pengindraan. Pengetahuan merupakan faktor penting dalam pembentukan tindakan seseoarang. Penginderaan terhadap objek terjadi melalui panca indra manusia yakni penglihatan, pendengaran, penciuman, rasa dan raba. Pada waktu pengindraan sampai menghasilkan pengetahuan, sangat dipengaruhi oleh intensitas perhatian persepsi terhadap obyek. Sebagian besar pengetahuan manusia diperoleh melalui mata dan telinga. ${ }^{(6)}$

Secara umum sikap dapat dirumuskan sebagai kecenderungan untuk merespon (secara positif atau negatif) terhadap orang, obyek atau situasi tertentu. Seseorang akan bersikap ketika terpapar informasi dari teman atau orang lain yang baru didengarnya. Konsep ini didukung oleh Newcomb, salah seorang ahli psikologi sosial yang dikutip Notoatmodjo menyatakan bahwa sikap merupakan reaksi atau respon dari seseorang terhadap suatu stimulus atau objek. ${ }^{(6)}$ Dalam hasil penelitian ini petani rumput laut telah mengetahui bahwa dengan menggunakan APD maka resiko terkena dermatitis kontak dapat dihindari.

\section{KESIMPULAN}

Berdasarkan hasil penelitian disimpulkan bahwa ada pengaruh penyuluhan terhadap peningkatan pengetahuan dan sikap petani rumput laut dalam penggunaan APD untuk pencegahan dermatitis kontak.

Bagi masyarakat Ohoi Ngilngof khususnya petani rumput laut disarankan agar menggunakan APD (Alat Pelindung diri) saat bekerja di laut. Dan kepala Ohoi Ngilngof memperhatikan petani rumput laut agar tetap memiliki Alat Pelindung Diri yang tersedia di Rumah.

\section{DAFTAR PUSTAKA}

1. Kemenkes RI. Kecelakaan kerja. 2013;

2. Kusnoputranto H. Kesehatan Lingkungan. jakarta; 2002.

3. Budiyono \& Cakrawati. Faktor Dermatitis Nelayan. 2011;

4. Brunner \& Suddarth. Keperawatan Medikal Bedah. Jakarta; 2013.

5. Anonim. Alat Pelindung Diri [Internet]. 2008. Available from: http//industrikimia.cara/tutorial/mengenal jenis alat pelindung diri

6. Notoatmodjo. Pendidikan Dan Perilaku Kesehatan. jakarta; 2003.

7. S.Aswar. Sikap Manusia.Teori dan perkembangannya. Yogyakarta; 2013.

8. Notoadmodjo. Metodologi Penelitian Kesehatan. jakarta; 2012.

9. Gemim Saputra Dan Halono Siregar. PengaruhPenyuluhan Metode Ceramah Dan Diskusi Kelompok Terhadap Peningkatan Pengetahuan Dan Sikap Pekerja Las Tentang APD Di Kecamatan Perut Sei Tuan. 2013;

10. Murtiyani. Pengaruh Metode Penyuluhan dengan leaflet Terhadap Pengetahuan Sikap Dan Perilaku Keluarga Dalam Pemberantasan DBD. 2011;

11. Permatasari. Diskusi Kelompok Efektif Dalam Meningkatkan Pengetahuan Dan Sikap Tentang Kesehatan Reproduksi Pada Remaja Di Yayasan Pendidikan Harapan Mekar Medan. 2010;

12. Arifah. Pengaruh Statistik Terhadap Peningkatan Pengetahuan Dan Sikap Wanita tentang Menopause Pada Pendidikan Kesehatan dengan Modul. 2010;

13. Notoadmodjo. Metodologi Penelitian Kesehatan. jakarta; 2010. 